Louisiana State University

LSU Digital Commons

$1-1-2014$

\title{
The carbon concentrating mechanism in Chlamydomonas reinhardtii: Finding the missing pieces
}

\author{
Nadine Jungnick \\ Louisiana State University \\ Yunbing $\mathrm{Ma}$ \\ Louisiana State University \\ Bratati Mukherjee \\ Louisiana State University \\ Julie C. Cronan \\ Louisiana State University \\ Dequantarius J. Speed \\ Louisiana State University
}

See next page for additional authors

Follow this and additional works at: https://digitalcommons.Isu.edu/biosci_pubs

\section{Recommended Citation}

Jungnick, N., Ma, Y., Mukherjee, B., Cronan, J., Speed, D., Laborde, S., Longstreth, D., \& Moroney, J. (2014). The carbon concentrating mechanism in Chlamydomonas reinhardtii: Finding the missing pieces. Photosynthesis Research, 121 (2-3), 159-173. https://doi.org/10.1007/s11120-014-0004-x 


\section{Authors}

Nadine Jungnick, Yunbing Ma, Bratati Mukherjee, Julie C. Cronan, Dequantarius J. Speed, Susan M. Laborde, David J. Longstreth, and James V. Moroney 


\title{
The carbon concentrating mechanism in Chlamydomonas reinhardtii: finding the missing pieces
}

\author{
Nadine Jungnick $\cdot$ Yunbing Ma $\cdot$ Bratati Mukherjee $\cdot$ Julie C. Cronan $\cdot$ \\ Dequantarius J. Speed $\cdot$ Susan M. Laborde $\cdot$ David J. Longstreth · \\ James V. Moroney
}

Received: 5 November 2013/Accepted: 8 April 2014/Published online: 22 April 2014

(C) Springer Science+Business Media Dordrecht 2014

\begin{abstract}
The photosynthetic, unicellular green alga, Chlamydomonas reinhardtii, lives in environments that often contain low concentrations of $\mathrm{CO}_{2}$ and $\mathrm{HCO}_{3}{ }^{-}$, the utilizable forms of inorganic carbon $\left(\mathrm{C}_{\mathrm{i}}\right)$. C. reinhardtii possesses a carbon concentrating mechanism (CCM) which can provide suitable amounts of $\mathrm{C}_{\mathrm{i}}$ for growth and development. This $\mathrm{CCM}$ is induced when the $\mathrm{CO}_{2}$ concentration is at air levels or lower and is comprised of a set of proteins that allow the efficient uptake of $\mathrm{C}_{\mathrm{i}}$ into the cell as well as its directed transport to the site where Rubisco fixes $\mathrm{CO}_{2}$ into biomolecules. While several components of the CCM have been identified in recent years, the picture is still far from complete. To further improve our knowledge of the $\mathrm{CCM}$, we undertook a mutagenesis project where an antibiotic resistance cassette was randomly inserted into the $C$. reinhardtii genome resulting in the generation of 22,000 mutants. The mutant collection was screened using both a published PCR-based approach (Gonzalez-Ballester et al.
\end{abstract}

Nadine Jungnick, Yunbing Ma and Bratati Mukherjee contributed equally to this work.

Electronic supplementary material The online version of this article (doi:10.1007/s11120-014-0004-x) contains supplementary material, which is available to authorized users.

N. Jungnick $\cdot$ Y. Ma $\cdot$ B. Mukherjee $\cdot$ J. C. Cronan ·

D. J. Speed · S. M. Laborde - D. J. Longstreth ·

J. V. Moroney $(\square)$

Department of Biological Sciences, Louisiana State University,

Baton Rouge, LA 70803, USA

e-mail: btmoro@1su.edu

Present Address:

Y. Ma

Department of Cell Biology and Anatomy, Louisiana State University Health Sciences Center, New Orleans, LA 70112, USA
2011) and a phenotypic growth screen. The PCR-based screen did not rely on a colony having an altered growth phenotype and was used to identify colonies with disruptions in genes previously identified as being associated with the CCM-related gene. Eleven independent insertional mutations were identified in eight different genes showing the usefulness of this approach in generating mutations in CCM-related genes of interest as well as identifying new CCM components. Further improvements of this method are also discussed.

Keywords Calvin-Benson-Bassham cycle $\cdot$ Carbon concentrating mechanism $\cdot$ Carbonic anhydrase .

Chlamydomonas $\cdot$ Rubisco
Abbreviations
CA Carbonic anhydrase
CBB cycle Calvin-Benson-Bassham cycle
CCM Carbon (dioxide) concentrating mechanism
Rubisco Ribulose-1,5-bisphosphate carboxylase/
$\begin{array}{ll}\text { RuBP } & \text { Ribugenase } \\ \text { Ribulose-bisphosphate }\end{array}$

\section{Introduction}

The vast majority of aquatic photosynthetic organisms rely on $\mathrm{CO}_{2}$ concentrating mechanisms (CCMs) to elevate the concentration of $\mathrm{CO}_{2}$ near the enzyme Rubisco. The CCM overcomes barriers to photosynthesis caused by the low dissolved $\mathrm{CO}_{2}$ concentration found in most aquatic environments and the slow diffusion of $\mathrm{CO}_{2}$ in water. Since aquatic photosynthetic organisms account for about $50 \%$ 
of the world's $\mathrm{CO}_{2}$ fixation, the emergence of a CCM is one of the most significant photosynthetic adaptations to the low atmospheric $\mathrm{CO}_{2}$ conditions experienced on earth over the past 30 million years (Giordano et al. 2005; Raven et al. 2011, 2012).

Photosynthesis in most terrestrial plants is limited by the $\mathrm{CO}_{2}$ concentration, particularly in hot and dry environments. A small percentage of terrestrial plants have adapted to low $\mathrm{CO}_{2}$ conditions using different $\mathrm{CO}_{2}$ concentrating mechanisms, namely $\mathrm{C}_{4}$ photosynthesis and Crassulacean acid metabolism. With improved $\mathrm{CO}_{2}$ fixation in mind, a number of international projects have worked to introduce $\mathrm{C}_{4}$ traits into crop plants, most notably rice (Gowik and Westhoff 2011; von Caemmerer et al. 2012). There is also considerable interest in introducing components of the CCMs from aquatic organisms into higher plants (Price et al. 2013). The underlying idea is that increasing the efficiency of $\mathrm{CO}_{2}$ fixation in higher plants could also lead to an improved tolerance to water stress. A CCM can also be expected to reduce wasteful photorespiration (Moroney et al. 2013). Computer simulations have indicated that the introduction of CCM components into higher plants could lead to significant increases in photosynthesis and decreases in photorespiration (Zhu et al. 2008). The introduction of CCM components from aquatic organisms into crop plants might lead to elevated $\mathrm{CO}_{2}$ levels around Rubisco, increasing photosynthesis and crop yield (Price et al. 2011; Zhu et al. 2008, 2010).

CCMs are found in cyanobacteria, chlorophytes, prasinophytes, and other types of algae, and it is thought that all of these lineages developed CCMs independently (Giordano et al. 2005; Meyer and Griffiths 2013). The best studied CCMs are from cyanobacteria and green algae. While the overall architecture of the CCMs from these two types of organisms is similar, the specific components that make up the CCMs of cyanobacteria and green algae differ greatly (Moroney et al. 2013). The CCM in prokaryotic cyanobacteria is the best understood and a number of laboratories are attempting to introduce components of the cyanobacterial CCM into higher plants (Price et al. 2004). This report will focus on the CCM from the eukaryotic green alga Chlamydomonas reinhardtii. $C$. reinhardtii is a eukaryote and the locations of the CCM components can be directly matched with the locations needed to improve higher plants photosynthetic efficiency. A working model of the $C$. reinhardtii CCM is shown in Fig. 1 and involves three key components. First, this model proposes that inorganic carbon transporters increase $C_{i}$ within the algal cell. Next, it is postulated that the pyrenoid, a structure in the chloroplast where most of the Rubisco is localized in the $C$. reinhardtii chloroplast, is analogous to the carboxysome of cyanobacteria and that the pyrenoid is the site of elevated inorganic carbon concentration. Finally, carbonic anhydrase (CA) activity is needed to convert accumulated bicarbonate to $\mathrm{CO}_{2}$, the actual substrate of Rubisco. In many ways, the CCM model for C. reinhardtii is similar to the models proposed for cyanobacteria, where bicarbonate transporters increase the $\mathrm{HCO}_{3}{ }^{-}$concentration within the cytoplasm, and then the accumulated $\mathrm{HCO}_{3}{ }^{-}$is converted to $\mathrm{CO}_{2}$ in the carboxysome where Rubisco is localized. It is important that the conversion to $\mathrm{CO}_{2}$ is confined within the carboxysome as it gives Rubisco an opportunity to fix the accumulated $\mathrm{CO}_{2}$ before it leaks out of the cell.

\section{The Chlamydomonas reinhardtii CCM}

and the unresolved aspects of the model

While the overall arrangement of the CCM in green algae and cyanobacteria is similar, there are some important differences. One major difference is the location of the $\mathrm{CA}$ that converts the $\mathrm{HCO}_{3}{ }^{-}$to $\mathrm{CO}_{2}$. In $C$. reinhardtii, the $\mathrm{CA}$, $\mathrm{CAH} 3$, is localized within the thylakoid lumen (Karlsson et al. 1998). It is thought that the placement of CAH3 in the acidic lumen helps to convert $\mathrm{HCO}_{3}{ }^{-}$to $\mathrm{CO}_{2}$ in a location that favors $\mathrm{CO}_{2}$ production, thus increasing the $\mathrm{CO}_{2}$ concentration. This implies that inorganic carbon transport proteins are needed on the thylakoid membrane as well as the chloroplast envelope (Fig. 1).

\section{Inorganic carbon transporters}

An important component of algal CCMs is the inorganic carbon transporter system. In cyanobacteria, three transporters are known: BicA, SbtA and Bct1 (Price 2011). Cyanobacteria lacking these transporters have very poor affinities for inorganic carbon (Price et al. 2004; Woodger et al. 2005). However, it has been found that at least two of these transporters must be knocked out before a clear growth phenotype is observed (Price et al. 2004) indicating that these CCM components may have overlapping functions. What we know about bicarbonate transporters in $C$. reinhardtii is less clear. Some possible inorganic carbon transporters found in $C$. reinhardtii are listed in Table 1 and are discussed in the next section.

\section{LCI1}

LCI1 was one of the first membrane proteins identified as being up-regulated under low $\mathrm{CO}_{2}$ conditions (Burow et al. 1996). The transcript for this protein is only present in cells grown under low $\mathrm{CO}_{2}$ conditions and its abundance increases dramatically when high $\mathrm{CO}_{2}$ grown cells are switched to low $\mathrm{CO}_{2}$ conditions. The regulation of LCI1 is also under the control of CIA5 and LCR1 (Fukuzawa et al. 2001; Miura et al. 2004). LCI1 has only weak homology to other transport proteins and no similarity with known 
Fig. 1 Model of the $\mathrm{CO}_{2}$ concentrating mechanism of Chlamydomonas reinhardtii. LCI1, HLA3, CCP1/2 and NAR1.2 are potential Ci transport proteins. CAH1, CAH3, CAH4/5, CAH6 and CAH8 are CAs
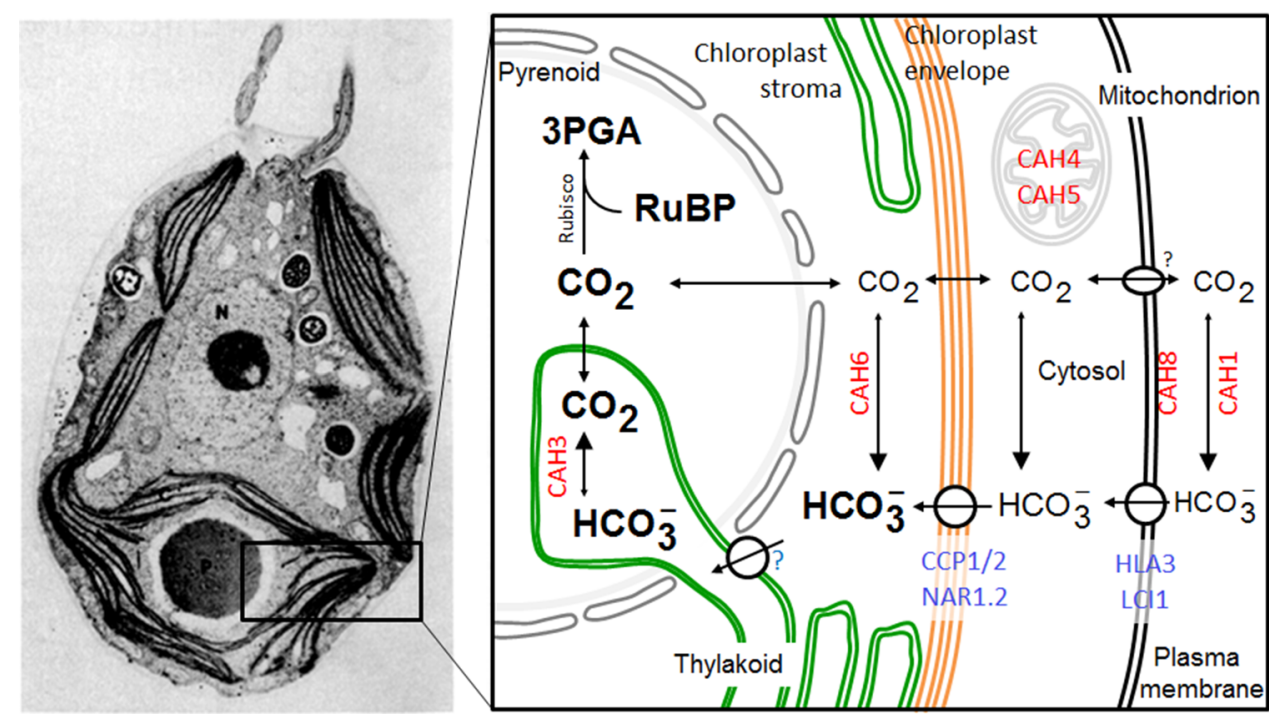

Table 1 Genes that encode potential inorganic carbon transporters

\begin{tabular}{|c|c|c|c|c|c|}
\hline Gene name & Phytozome gene ID & Protein location & $\begin{array}{l}\mathrm{Up} \text { - } \\
\text { regulated } \\
\text { on low } \mathrm{CO}_{2}\end{array}$ & $\begin{array}{l}\text { Regulated } \\
\text { by CIA5 }\end{array}$ & $\begin{array}{l}\text { RNAi strain/complete } \\
\text { knock out }\end{array}$ \\
\hline$L C I 1$ & Cre03.g162800 & Plasma membrane & Yes++ & Yes & Yes/yes \\
\hline NAR1.2 & Cre06.g309000 & Chloroplast envelope & Yes++ & Yes & Yes/no \\
\hline$C C P 1$ & Cre04.g223300 & Chloroplast envelope & Yes ++ & Yes & Yes/yes \\
\hline$C C P 2$ & Cre04.g222750 & Chloroplast envelope & Yes++ & Yes & Yes/yes \\
\hline$H L A 3$ & Cre02.g097800 & Plasma membrane & Yes++ & Yes & Yes/no \\
\hline $\begin{array}{l}\text { Bestrophin } \\
\text { /LCI11 }\end{array}$ & Cre16.g663450 & Unknown & Yes & Yes & No \\
\hline MITC11 & Cre06.g295400 & Unknown & Yes & Yes & No \\
\hline NAR1.1 & AF149738 ${ }^{1}$ & Unknown & No & No & No \\
\hline NAR1.3 & g4546 & & & & \\
\hline NAR1.4 & Cre07.g35600 & & & & \\
\hline NAR1.5 & Cre12.g541250 & & & & \\
\hline NAR1.6 & Cre01.g012050 & & & & \\
\hline
\end{tabular}

${ }^{1}$ NAR1.1 has no gene model in the current Phytozome version (Phytozome version 9.1, Chlamydomonas genomic information: v5.3.1 of Chlamydomonas annotations, based on the Augustus update u11.6 of JGI assembly v5.). The NCBI accession number is given instead for sequence information

$\mathrm{HCO}_{3}{ }^{-}$transporters. However, when introduced into $C$. reinhardtii in the absence of other CCM components, LCI1 elicits an increase in $\mathrm{C}_{\mathrm{i}}$ uptake (Ohnishi et al. 2010). LCI1 has been localized to the plasma membrane but so far no LCI1 mutant has been identified or generated.

\section{NAR1.2}

NAR1.2, also called LCIA, is up-regulated under low $\mathrm{CO}_{2}$ conditions and was one of the first up-regulated proteins with transporter properties (Miura et al. 2004). Originally annotated as a possible nitrite transporter, it belongs to a small protein family with six members that show structural similarity to the wide spread group of Formate/Nitrite transporters (PF01226) (Mariscal et al. 2006). NAR1.2 is also considered to be a $\mathrm{HCO}_{3}{ }^{-}$transporter because its presence correlates well with the CCM, and its synthesis is controlled by CIA5 (Miura et al. 2004). It has been localized to the chloroplast envelope (Mukherjee 2013). Overexpression of NAR1.2 in Xenopus oocytes indicates it can transport both nitrite and bicarbonate (Mariscal et al. 2006). Interestingly, NAR1.2 does not have a close paralog in higher plants.

\section{Other NAR proteins}

NAR1.1 through NAR1.6 comprises a small family of proteins in $C$. reinhardtii. Like NAR1.2, all of these 
proteins belong to the Formate/Nitrite family of transporters. They vary considerably in their $\mathrm{N}$-terminal domain and are predicted to target to different membranes. Unlike NAR1.2, the synthesis of these proteins does not correlate well with the synthesis of the CCM (Mukherjee 2013) but their structural similarity in $C$. reinhardtii could indicate a role in the CCM.

\section{HLA3}

First identified as a transcript that increases in abundance under high light conditions (Im and Grossman 2002), HLA3 also increases under low $\mathrm{CO}_{2}$ conditions and is regulated by CIA5. This protein is an ABC-type transport protein. RNAi strains with reduced expression of both NAR1.2 and HLA3 grew poorly on low $\mathrm{CO}_{2}$ (Duanmu et al. 2009).

\section{$\mathrm{CCP} 1 / \mathrm{CCP} 2$}

CCP1 and CCP2 are two very closely related proteins localized to the chloroplast envelope (Ramazanov et al. 1993). $\mathrm{CCP} 1$ and $\mathrm{CCP} 2$ are both strongly up-regulated by growth in low $\mathrm{CO}_{2}$, and their expression is controlled by CIA5. CCP1 and CCP2 are members of the mitochondrial carrier protein family which includes many transporters of metabolites and are found in other locations in the cell besides the mitochondria. Pollock et al. (2004) reported an RNAi line of C. reinhardtii that showed reduced expression of both genes. This strain grew poorly on low $\mathrm{CO}_{2}$ but still accumulated $\mathrm{C}_{\mathrm{i}}$ normally and had a normal affinity for external $\mathrm{C}_{\mathrm{i}}$ as judged by photosynthesis assays (Pollock et al. 2004).

\section{Other transport proteins}

Other genes that might be part of the CCM have been identified from two recent reports using RNA sequencing (Brueggeman et al. 2012; Fang et al. 2012). These include the transmembrane proteins bestrophin and MITC11. The transcripts for both bestrophin/LCI11 and MITC11 are strongly up-regulated under low $\mathrm{CO}_{2}$ growth conditions (Brueggeman et al. 2012) and appear to be regulated by CIA5 (Fang et al. 2012). In other systems, bestrophins function as anion channels transporting mostly chloride, but bicarbonate was also identified as a transported molecule for human bestrophins (Qu and Hartzell 2008). MITC11 shows homologies to mitochondrial carrier proteins although localization predictions for MITC11 indicate that it is a chloroplast protein.

The above mentioned proteins belong to a number of different protein families but all have the potential to function as inorganic carbon transporters. The evidence that these proteins participate in the CCM comes from the observation that the synthesis of most of these proteins is highly correlated with the presence of the CCM in $C$. reinhardtii. In addition, the synthesis of these proteins is regulated by CIA5 (CCM1), a protein that controls the synthesis of many other CCM components (Moroney et al. 1989; Fukuzawa et al. 2001; Xiang et al. 2001). Thus, a number of promising $\mathrm{C}_{\mathrm{i}}$ transporter candidates have been identified. However, there are no knock-out lines for any of these putative transporters and only a few RNAi strains have been generated. It is also clear that the CCM is regulated by light as there is no $\mathrm{C}_{\mathrm{i}}$ uptake in the dark (Moroney et al. 1987). Sültemeyer et al. (1989) reported that the regulation of the CCM takes place over a very short time during a light/dark transition. This regulation of $\mathrm{C}_{\mathrm{i}}$ transporters by light is also seen in cyanobacteria. However, we need to identify the regulating protein(s) that are required for activation of these transporting proteins especially if these regulators are necessary for the successful introduction of a CCM into higher plants. In addition, for most of the transport proteins it is not clear what $\mathrm{C}_{\mathrm{i}}$ species they transport or whether they function as symporters or antiporters. It has been established that two of the cyanobacterial $\mathrm{C}_{\mathrm{i}}$ transporters are $\mathrm{Na}^{+}-\mathrm{HCO}_{3}{ }^{-}$co-transporters (Price 2011). Similarly in $C$. reinhardtii, it needs to be established which of these proteins transport $\mathrm{HCO}_{3}{ }^{-}$and which require some other ion in addition to $\mathrm{HCO}_{3}{ }^{-}$to function.

\section{Rubisco and the pyrenoid}

The pyrenoid is the site for $\mathrm{CO}_{2}$ fixation by Rubisco in $C$. reinhardtii. C. reinhardtii mutant strains lacking Rubisco also lack an observable pyrenoid (Borkhsenious et al. 1998). In mutants in which Rubisco becomes unstable and breaks down at elevated temperatures, the pyrenoid is also lost at non-permissive temperatures (Rawat et al. 1996). Immunolocalization studies from multiple laboratories also support the conclusion that over $90 \%$ of the Rubisco is in the pyrenoid in $C$. reinhardtii cells grown under low $\mathrm{CO}_{2}$ conditions (Morita et al. 1997; Borkhsenious et al. 1998). Finally, there is just enough Rubisco in the cell to support the maximal rates of photosynthesis (Borkhsenious et al. 1998) indicating that Rubisco in the pyrenoid is active and that the pyrenoid is the site of $\mathrm{CO}_{2}$ fixation (Borkhsenious et al. 1998).

What other proteins are in the pyrenoid?

A recent study indicates that none of the other CBB cycle enzymes are found in the pyrenoid of $C$. reinhardtii (Mettler and Stitt, personal communication). So the enzymatic composition of the pyrenoid is similar to the carboxysome which also lacks CBB enzymes other than Rubisco. In $C$. reinhardtii, the only other protein that has 
been localized to the pyrenoid is Rubisco activase (McKay et al. 1991).

Besides the electron-dense soluble part of the pyrenoid, the pyrenoid of $C$. reinhardtii is penetrated by thylakoid tubules (Rawat et al. 1996). Little is known about the protein composition of the tubules except that CAH3 has been detected in the tubules. Recently Flor Martinez and her colleagues found that CAH3 was phosphorylated in the light and that this phosphorylation might be activating and possibly relocating CAH3 to the tubules within the pyrenoid (Blanco-Rivero et al. 2012). Based on these findings, the model of the $C$. reinhardtii CCM can be fine-tuned. Bicarbonate is enriched in the chloroplast and finally transported into the lumen of the thylakoids which also pervade the pyrenoid. This bicarbonate is then converted by $\mathrm{CAH} 3$ into $\mathrm{CO}_{2}$ that is subsequently fixed by Rubisco in the pyrenoid.

The pyrenoid is a dynamic structure

The appearance of the pyrenoid of $C$. reinhardtii changes dramatically depending on whether the cells are grown on low or high $\mathrm{CO}_{2}$. Under low $\mathrm{CO}_{2}$ growth conditions, the pyrenoid becomes much more defined and is surrounded by a starch sheath (Mason et al. 1991). Later studies showed that Rubisco is more evenly distributed in the chloroplast stroma under high $\mathrm{CO}_{2}$ growth conditions but becomes predominantly, if not exclusively localized to the pyrenoid under low $\mathrm{CO}_{2}$ growth conditions (Borkhsenious et al. 1998). Furthermore it has been shown that the distribution of starch and Rubisco changes depending on the growth conditions of the cells. The starch sheath around the pyrenoid is more pronounced and denser under low $\mathrm{CO}_{2}$ (Ramazanov et al. 1993; Borkhsenious et al. 1998). The current hypothesis, based on this finding is that the starch sheath functions as a diffusion barrier for $\mathrm{CO}_{2}$ that prevents the leakage and therefore enhances the fixation of $\mathrm{CO}_{2}$ under limiting conditions. More recent studies indicate LCIB also localizes to the perimeter of the pyrenoid under low $\mathrm{CO}_{2}$ growth conditions. It has been postulated that LCIB might act as an additional barrier to the diffusion of $\mathrm{CO}_{2}$ out of the pyrenoid (Yamano et al. 2010). Finally, it has been reported that $\mathrm{CAH} 3$ could move into the pyrenoid tubules when $C$. reinhardtii is grown under low $\mathrm{CO}_{2}$ growth conditions (Sinetova et al. 2012). All of these observations underscore the dynamic nature of the pyrenoid and its important role in the CCM of $C$. reinhardtii.

Is the pyrenoid required for a functional CCM?

Studies from the Griffiths and Spreitzer research groups indicate that a functional pyrenoid might be needed for the operation of a functional CCM (Genkov et al. 2010; Meyer et al. 2012). They substituted regions of the Rubisco small subunits of $C$. reinhardtii by swapping in higher plant subunits or parts of higher plant subunits. The substitution of the higher plant sequences did not change the catalytic properties of the Rubisco protein but still resulted in $C$. reinhardtii cells that failed to grow under low $\mathrm{CO}_{2}$ conditions. It was notable that in many cases the pyrenoid was absent in these cells. These observations imply that Rubisco must be tightly packaged for a CCM to work. The cia6 mutant provided an additional line of evidence that a pyrenoid structure is required for CCM function. This mutant has a poorly organized pyrenoid and grows more slowly than wild-type cells on low $\mathrm{CO}_{2}$ (Ma et al. 2011). These observations support the idea that the pyrenoid is required for CCM function and that other proteins besides Rubisco are important in determining the pyrenoid structure.

\section{CA proteins involved in the CCM}

CAs are required for CCM function. Since CCMs accumulate $\mathrm{HCO}_{3}{ }^{-}$, the conversion of $\mathrm{HCO}_{3}{ }^{-}$to $\mathrm{CO}_{2}$ before fixation by Rubisco is an essential part of any CCM. The $C$. reinhardtii genome has been sequenced and we have considerable evidence on the number and location of the CA proteins in this alga (Moroney et al. 2011; Table 2). The CA genes, $C A H 1, C A H 4$ and $C A H 5$ are strongly upregulated under low $\mathrm{CO}_{2}$ growth conditions (Ynalvez et al. 2008). CAH1 is localized to the periplasmic space while CAH4 and CAH5 are localized to the mitochondria. CAH1 is thought to be important in the delivery of inorganic carbon to the cell (Moroney et al. 1985). However, a mutant missing CAH1 grows at near normal rates even under low $\mathrm{CO}_{2}$ conditions (Van and Spalding 1999). The other two CAs up-regulated under low $\mathrm{CO}_{2}$ are $\mathrm{CAH} 4$ and CAH5 (Villand et al. 1997). Mutants for both proteins would increase understanding of their functions.

One CA with a very well understood role in the CCM is CAH3 which is localized to the chloroplast thylakoid lumen (Karlsson et al. 1998). A number of knock-out strains of CAH3 exist (Karlsson et al. 1998), and all of these mutants require elevated $\mathrm{CO}_{2}$ for growth (Hanson et al. 2003). It is thought that $\mathrm{CAH} 3$ converts accumulated $\mathrm{HCO}_{3}{ }^{-}$in the chloroplast to $\mathrm{CO}_{2}$ for fixation by Rubisco in the pyrenoid (Sinetova et al. 2012). The roles of the other CAs, most notably CAH6, CAH7 and CAH8 are not known yet.

The identification of CCM components

CCM components have previously been identified using two approaches. The first approach uses forward genetics done by mutagenizing cells and screening for colonies that 
Table 2 The CAs of Chlamydomonas reinhardtii

The transcript level of these two CAs are higher in the CIA5 mutant compared to the wild type according to Fang et al. (2012)

\begin{tabular}{llllll}
\hline $\begin{array}{l}\text { Gene name (CA } \\
\text { type) }\end{array}$ & $\begin{array}{l}\text { Phytozome gene } \\
\text { ID }\end{array}$ & $\begin{array}{l}\text { Protein } \\
\text { location }\end{array}$ & $\begin{array}{l}\text { Regulated on low } \\
\mathrm{CO}_{2}\end{array}$ & $\begin{array}{l}\text { Regulated by } \\
\text { CIA5 }\end{array}$ & $\begin{array}{l}\text { Knock } \\
\text { out }\end{array}$ \\
\hline$C A H 1(\alpha)$ & Cre04.g223100 & Periplasm & Yes+ & Yes & Yes \\
$C A H 2(\alpha)$ & Cre04.g223050 & Periplasm & No & Unknown & No \\
$C A H 3(\alpha)$ & Cre09.g415700 & Thylakoids & No & No & Yes \\
$C A H 4(\beta)$ & Cre05.g248400 & Mitochondria & Yes+ & Yes & No \\
$C A H 5(\beta)$ & Cre05.g248450 & Mitochondria & Yes+ & Yes & No \\
$C A H 6(\beta)$ & Cre12.g485050 & Chloroplast & No & No & No \\
$C A H 7(\beta)$ & Cre13.g607350 & Unknown & No & Unknown & No \\
$C A H 8(\beta)$ & Cre09.g405750 & Plasma & No & Yes & No \\
& & membrane/ & & & Yes ${ }^{\mathrm{a}}$ \\
$C A H 9(\beta)$ & g5283 & Cytoplasm & No & No \\
\hline
\end{tabular}

grew poorly under low $\mathrm{CO}_{2}$ but well on high $\mathrm{CO}_{2}$. Initially chemical or UV mutagenesis was employed and mutants of CAH3, LCIB and CIA5 were first identified using these methods (Spalding et al. 1983a; Moroney et al. 1986, 1989). More recently, insertional mutagenesis has been used as it is easier to identify the disrupted gene once a mutant has been identified. This approach has generated a number of CCM mutants (e.g. cia6), photosynthesis mutants and a strain defective in Rubisco activase (Pollock et al. 2003; Dent et al. 2005; Ma et al. 2011).

The second approach involves looking for genes or proteins strongly up-regulated under low $\mathrm{CO}_{2}$ growth conditions. This strategy began by using ${ }^{35} \mathrm{~S}$-labeled proteins and has evolved through different techniques including differential display, microarray analysis and more recently, RNA sequencing (Miura et al. 2004; Yamano and Fukuzawa 2009; Brueggeman et al. 2012; Fang et al. 2012). In some cases, most notably LCIB, both the mutant screen and differential expression have identified the same protein (Spalding et al. 1983b; Duanmu et al. 2009).

The identification and characterization of CCM genes using these methods has significantly contributed to the understanding of the $C$. reinhardtii CCM. However, forward genetics screens have their limitations since only mutants with a noticeable phenotype can be isolated and characterized. Not all mutants exhibit a certain phenotype, especially in a general mutagenesis phenotype screen. For example, the CAHl mutants (cahl and CC-503) do not have dramatic phenotypes especially under normal $\mathrm{pH}$ growth conditions (Van and Spalding 1999; Mukherjee et al. 2012). It is also likely that disruption of some of the genes controlled by CIA5 will not lead to an obvious growth phenotype. Miura et al. (2004) showed that CIA5 controlled at least 52 genes and more recently Fang et al. (2012) demonstrated that loss of CIA5 led to expression changes in over 1,000 genes. So, while cia5-deficient strains grow poorly on low $\mathrm{CO}_{2}$, the alga still survives.
Therefore it seems likely that knocking out some of the genes controlled by CIA5 would lead to only subtle growth differences and that these differences might be missed using a phenotypic screen. In addition, if two genes encode proteins with redundant functions, cells defective in one of the genes would not be expected to exhibit a growth phenotype. Finally, the identification of CCM genes based on expression studies also has its limitations. For example $\mathrm{CAH} 3$, a CA essential to the CCM, is constitutively expressed.

As detailed in this article, a collection of CCM mutants has already been generated and characterized. These mutants can often be acquired from the $C$. reinhardtii Center. However, a large number of proposed CCM genes do not have a corresponding mutant, which hinders understanding the specific role of each component and the development of the entire CCM network. For example, the chloroplast stroma CA, CAH6 has been postulated to play an important role in $\mathrm{CO}_{2}$ fixation by reducing the leakage of $\mathrm{CO}_{2}$ out of the chloroplast thus maintaining the elevated $\mathrm{CO}_{2}$ concentration around Rubisco (Yamano and Fukuzawa 2009). CAH6 has also been proposed to be associated with the pyrenoid, and a chloroplast stroma protein LCIB (Yamano et al. 2010). The identification of a CAH6 mutant would be most beneficial to the CCM community.

Recently, a large scale insertional mutagenesis protocol which employed a PCR-based screen to identify cells with an insertion in a gene of interest was published (GonzalezBallester et al. 2011). The speed and efficiency of the PCRbased mutant screening was dramatically increased by incorporating DNA pooling from a number of transformants and a primer cocktail for each specific gene. Starting with a 100,000-mutant library, a total of 45 mutants were identified with insertions in 37 different genes out of 63 screened (Gonzalez-Ballester et al.2011). This powerful tool can also be adapted for the identification of missing mutants for CCM genes. 
Overall strategy for the new CCM mutant screen

We have conducted an insertional mutagenesis screen employing a PCR-based reverse genetics approach to obtain more mutants in which potential CCM genes are disrupted. Two different screening methods were followed. First a phenotypic screen was employed using cells grown on low $\mathrm{CO}_{2}(200 \mathrm{ppm})$. Genes disrupted in mutants unable to grow well on low $\mathrm{CO}_{2}$ were identified using iPCR. The second screen was a reverse genetics PCR-based screen where inserts were identified using PCR primer mixtures for specific genes (Supplemental Table S1) along with primers that anneal in the inserted cassette. The overall strategy in the PCR-based screen was similar to that described by Gonzalez-Ballester et al. (2011). C. reinhardtii cells were first transformed using an AphVIII cassette, which confers resistance to paromomycin. After mutagenesis, the genomic DNA from the paromomycin resistant transformants was pooled together to serve as the PCR template and screened for the presence of the AphVIII cassette in specific genes. A total of 22,860 insertional mutants were generated, and 71 genes that are possibly involved in the CCM were screened (Supplemental Table 1).

\section{Experimental procedures}

\section{Generating mutants}

The overall experimental procedure is shown in Fig. 2. Mutant selection was performed using paromomycin as the selective antibiotic. The paromomycin resistance cassette (AphVIII cassette) was obtained from the plasmid pSL18 (Depege et al. 2003). Using restriction enzymes, a DNA fragment comprised of the $H s p 70+R b c S I I$ dual promoter, the ORF of the paromomycin resistance gene: aminoglycoside $3^{\prime}$-phosphotransferase (AphVIII) (Sizova et al. 2001), and the RbcSII terminator was obtained. The linear, purified AphVIII cassette (100 ng linearized DNA per $300 \mu \mathrm{l}$ cell suspension with a density of $2 \times 10^{8}$ cells per $\mathrm{ml}$ in standard TAP medium supplemented with $60 \mathrm{mM}$ Sorbitol) was transformed into the strain D66 by electroporation (Shimogawara et al. 1998). Before electroporation, D66 was grown in minimal medium to midlog phase in high $\mathrm{CO}_{2}$ and then switched to low $\mathrm{CO}_{2}$ for $3 \mathrm{~h}$ prior to transformation. This was done to target insertions to genomic regions that are actively transcribed during the acclimation to a low $\mathrm{CO}_{2}$ stress condition. Overall, 197 individual transformations were conducted, and a total of 22,860 paromomycin resistant mutants were obtained.
Culture maintenance and DNA preparation

Agar plates with a 180-colony grid were used for cell growth and kept in low light $\left(50 \mu \mathrm{mol}\right.$ photons $\left.\mathrm{m}^{2} / \mathrm{s}\right)$. Fungal contamination was controlled by supplementing plates with carbendazim $(70 \mu \mathrm{g} / \mathrm{ml})$. A total of 135 agar plates were generated and replica-plated monthly. For DNA preparation, all 180 colonies from one plate were combined and the DNA was extracted (Supplemental Materials). DNA preparations from five such plates were further combined (referred to as "pooled DNA" in the text) to allow for the simultaneous screening of 900 individual colonies in a PCR screen. Thus, DNA from 135 plates was used to produce 27 DNA pools for the PCR screen.

\section{Low $\mathrm{CO}_{2}$ screen}

The low $\mathrm{CO}_{2}$-growth screen was performed as previously described (Colombo et al. 2002; Pollock et al. 2003). Cells were replica plated onto minimal medium plates and grown under low $\mathrm{CO}_{2}\left(200\right.$ ppm $\left.\mathrm{CO}_{2}\right)$ for 10 days at continuous light $\left(50 \mu \mathrm{mol}\right.$ photons $\left.\mathrm{m}^{2} / \mathrm{s}\right)$. Colonies that grew more slowly than the wild-type strain (D66) were further characterized. Colonies were then replica plated onto two more minimal plates and grown on both high $\mathrm{CO}_{2}\left(2 \% \mathrm{CO}_{2}\right.$ in air) and again on low $\mathrm{CO}_{2}\left(200 \mathrm{ppm} \mathrm{CO}_{2}\right)$ for 10 days. This growth test was repeated. Colonies that reproducibly grew poorly on low $\mathrm{CO}_{2}$ were analyzed via iPCR to find the insert location.

\section{iPCR}

We followed a published iPCR protocol (Colombo et al. 2002) with minor modifications. In brief, DNA was extracted (Supplemental Materials) from cells with a low $\mathrm{CO}_{2}$ phenotype and one $\mu \mathrm{g}$ digested with blunt end cutting restriction enzymes (PmlI and PvuII) that generate approximately 3,000-4,000 bp genomic fragments but do not cut within AphVIII cassette. The fragmented DNA was purified with phenol/chloroform, ligated to form circular DNA and used for a three step PCR protocol with three different nested Primer sets $(\mathrm{RB} 1+\mathrm{RX} 2, \mathrm{RB} 2+\mathrm{RX} 1$, $\mathrm{RB} 3+\mathrm{RX} 1)$. Amplified products of the last PCR that showed a progressive enrichment at each successive nested reaction were gel purified and sequenced. Sequences were then aligned to the annotated $C$. reinhardtii genome.

\section{Growth at low $\mathrm{CO}_{2}$ at different $\mathrm{pH}$}

For testing growth on solid media and under different $\mathrm{pH}$ levels, equal numbers of cells from different strains were spotted on minimal medium plates maintained at different $\mathrm{pH}$ levels by the addition of the following buffers: $25 \mathrm{mM}$ 
Fig. 2 Overall strategy for the dual phenotypic and PCR screens for potential CCM mutants. A linear, purified cassette mediating paromomycin resistance (AphVIII cassette) was transformed into cells of the $C$. reinhardtii strain D66 by electroporation. Transformants were selected on TAP plus paromomycin and surviving colonies were maintained on large plates with 180 colonies per plate. For the phenotypic screen, colonies were replica plated and grown at low and high $\mathrm{CO}_{2}$. Growth was compared to control strains and strains deficient in various $\mathrm{CCM}$ proteins. For the PCR screen, DNA from all 180 colonies on a plate was extracted and further pooled with DNA from four other plates. A number of target genes were selected and the DNA pools were subjected to multiple rounds of PCR based on primers for these target genes. The pooled DNA allowed rapid screening of the selected colonies

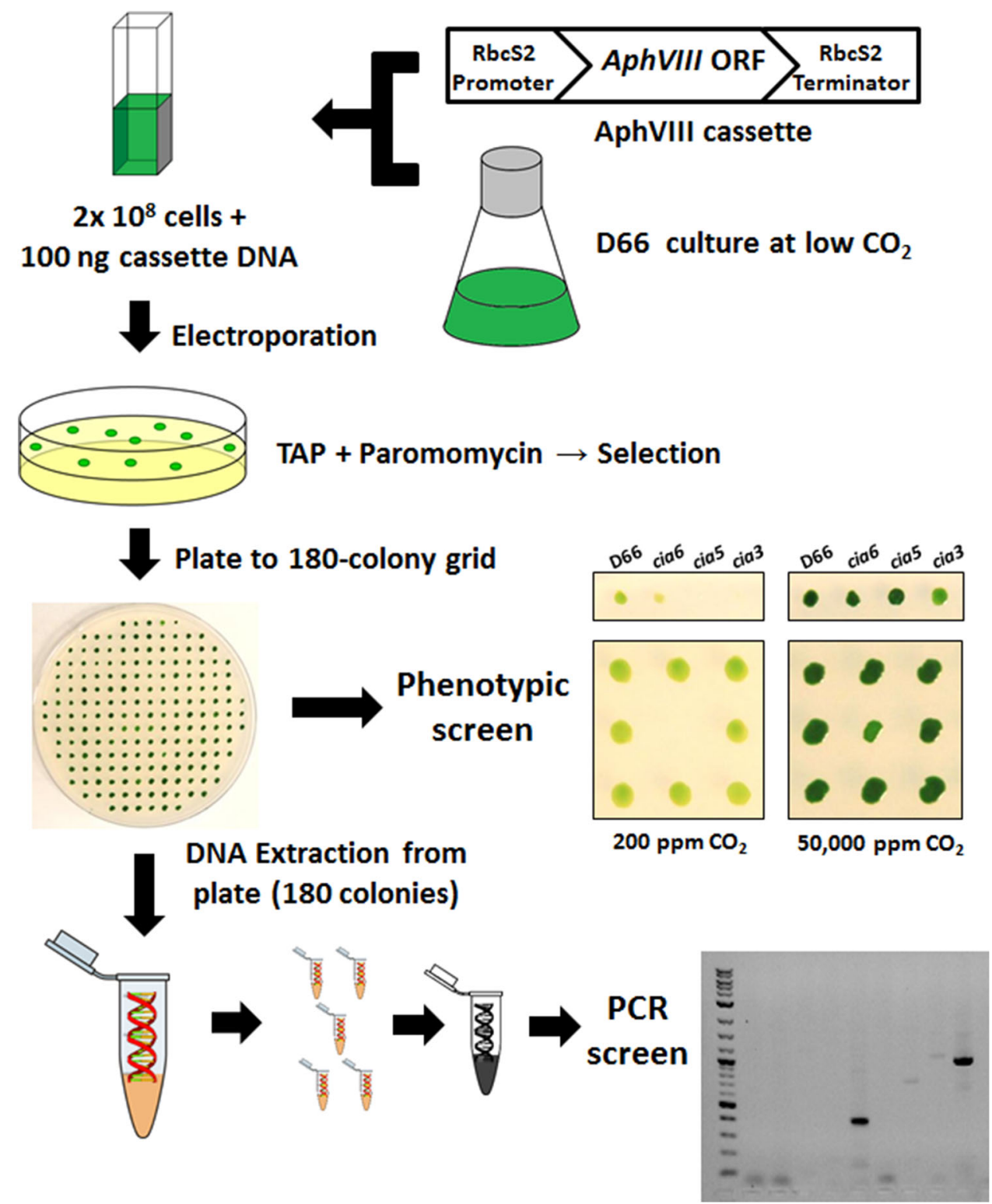

MES (pH 5.8 and 6.2), $25 \mathrm{mM}$ MOPS (pH 7.2) and $25 \mathrm{mM}$ HEPES ( $\mathrm{pH}$ 8.2). The plates incubated in chambers maintained at high and low $\mathrm{CO}_{2}$ conditions for 10 days under continuous illumination of roughly $50 \mu \mathrm{mol}$ photons $\mathrm{m}^{2} / \mathrm{s}$.

\section{PCR screen overview}

A PCR-based reverse genetics screen was used to identify mutants with modifications in specific genes potentially involved in the CCM. Briefly, the potential CCM genes were selected based on previous knowledge and published bioinformatics data (Supplemental Table 1). Primers were designed and PCR screens using primer mixes were performed on DNA pools. PCR signals were validated first by multiple rounds of PCR and then by sequencing. Finally, single colonies that produced the positive signals were identified. An example on an insert in the CAH8 gene is shown in Fig. 3.

Gene selection

Two groups of genes were selected as PCR targets (Supplemental Table 1). The first group consisted of genes that had been previously characterized and/or proposed as essential CCM components in C. reinhardtii or components of the photorespiratory pathway. The second group was chosen from nearly 2,000 genes identified as up-regulated by low $\mathrm{CO}_{2}$ in two recent publications (Brueggeman et al. 2012; Fang et al. 2012). Other criteria considered for 


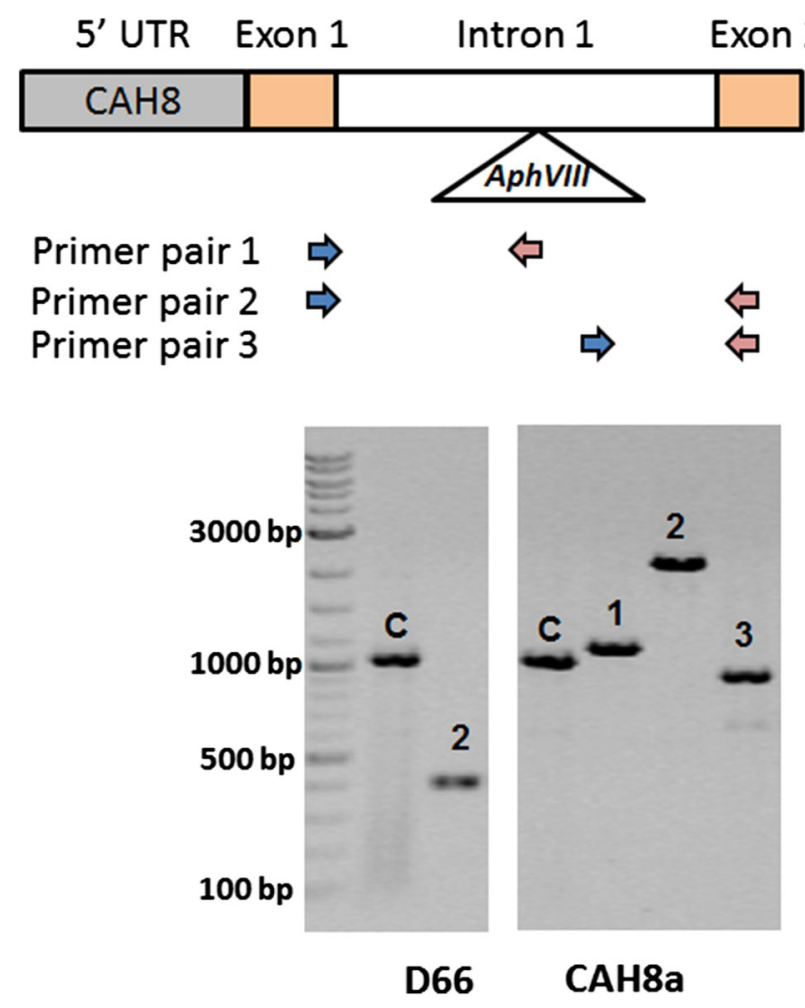

Fig. 3 PCR strategy for mapping the insert. At the top is a depiction of the $5^{\prime}$ end of the $C A H 8$ gene showing the first two exons and introns. Beneath the gene map the locations of the primer pairs used are shown. At the bottom are the PCR products using genomic DNA from the cah8a strain. "C" indicates a PCR control and the numbers above the band indicates the used primer pair. The two insert specific genes RB2 ( $3^{\prime}$ end of insert) and RX2 (5' end of insert) were used with the gene specific primers CAH R5 and CAH F2 respectively to analyze the regions flanking the insert. Primer sequences are given in Supplemental Table 2

the second group of PCR target genes included possible chloroplast localization and predicted transmembrane domains in addition to exhibiting large changes in transcript levels between high and low $\mathrm{CO}_{2}$ growth conditions. The target genes were listed in the order of their relative physical locations on the chromosomes in Supplemental Table 1.

Primer designs for the selected genes

To design primers for one specific gene (all the gene models used were based on Augustus 5 models, http:// genome.jgi-psf.org/Chlre4/Chlre4.home.html), two sets of primers covering both directions were designed along the locus, spaced approximately 1-kb from each other. Primer design followed a published method (Gonzalez-Ballester et al. 2011) with a few modifications. The first forward (F1) and the first reverse (R1) primer were positioned 20-200 bp beyond the $5^{\prime}$ UTR or $3^{\prime}$ UTR respectively.
PCR procedure

For a specific gene, all the forward primers were combined together (designated as " $F$ ") and all the reverse primers were combined together (designated as "R"). For each gene, two PCRs were performed by pairing the AphVIII internal primer RB1 (Gonzalez-Ballester et al. 2011) with either F or R. Whenever a pool produced a PCR product and that product was verified with the second AphVIII internal primer, RB2, DNA from each plate used in that product was screened. Whenever the same PCR product was observed from a PCR reaction using DNA from a specific plate the exact forward or reverse primer paired with RB1 that produced the product was determined. The PCR products were verified by sequencing. Then that primer pair was used to identify the specific colony with the insert of interest. After the mutant was determined on the single colony level, single colonies from each mutant colony were further isolated. PCR analysis from five random colonies was performed to ensure the homogeneity of the mutant colony. Furthermore, the insertion bordering DNA sequence was analyzed to verify whether the inserted AphVIII cassette caused deletions or other DNA alteration at the insertion site (Fig. 3).

\section{Results}

Phenotypic screen on low $\mathrm{CO}_{2}$

Thirty-seven colonies from the screened 22,000 insertional mutants consistently showed a slow-growth phenotype on low $\mathrm{CO}_{2}$. On elevated $\mathrm{CO}_{2}$, these colonies grew at the same rate as wild-type cells. Four examples are shown in Fig. 4 and DNA flanking the insert was obtained for these mutants using iPCR. The locations of the AphVIII DNA inserts were found for four mutants (M7, M16, M17 and M19) and included insertions in the following genes: a glycerol-3-phosphate dehydrogenase (Phytozome ID: Cre01.g053150, M7), a leucyl-tRNA synthase (g14211, M16) a flagellar membrane protein FMG1-B (g9144, M17), and a signal recognition particle (SRP54) associated GTPase (Cre11.g479750, M19) (Table 3). The AphVIII cassette was inserted into intronic regions in the mutants M7, M16 and M19 (Table 3). The sequencing information of M17 showed an insertion into the third exon of the FMG1-B gene.

PCR-based screen

Using the 22,000 insertional mutants, eleven different mutants were found with inserts in eight different targeted genes of interest (Table 4). Exonic insertions were found 

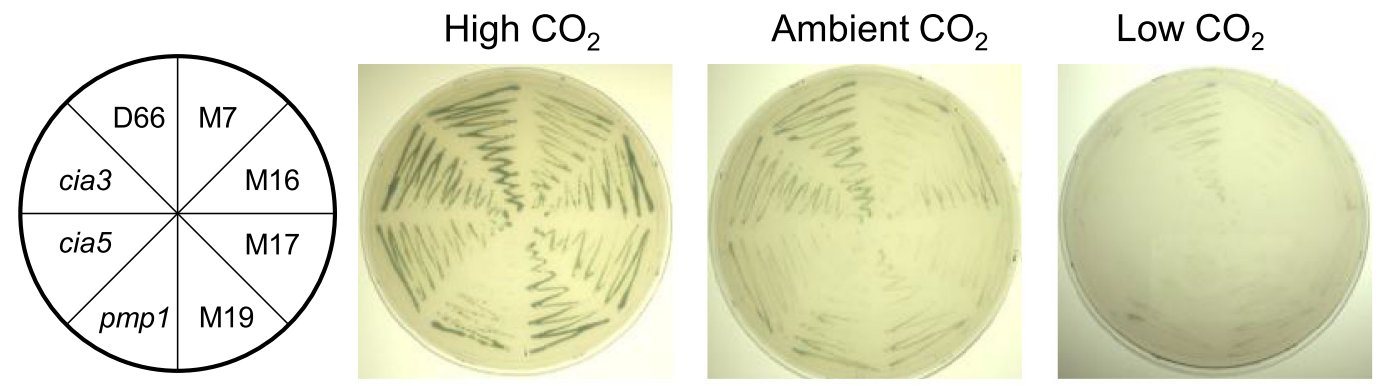

$\mathrm{pH} 6.2$
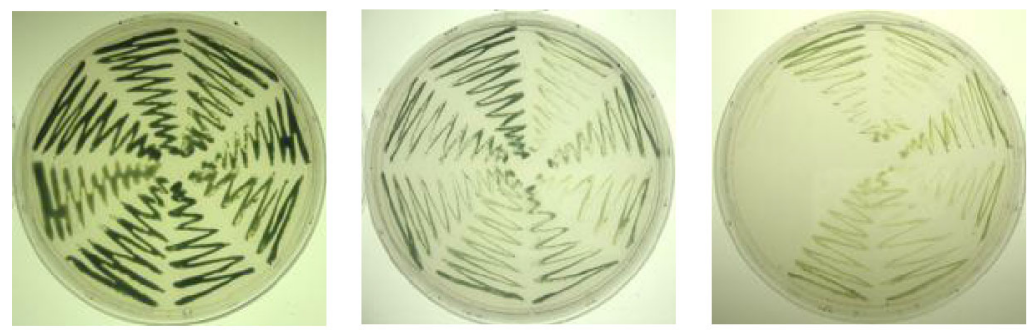

$\mathrm{pH} 7.2$
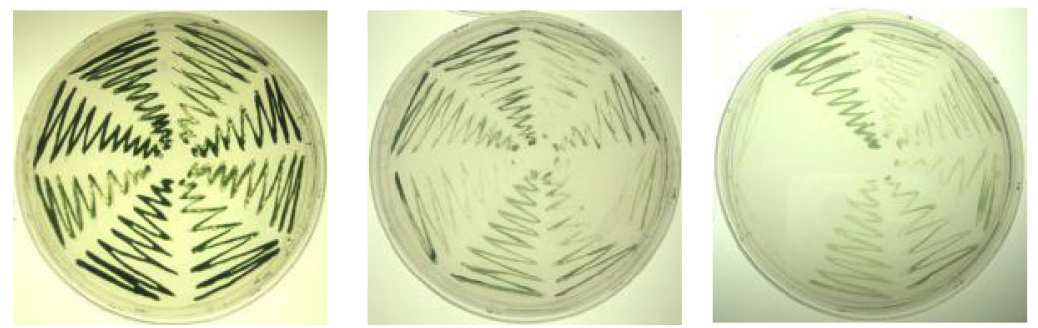

$\mathrm{pH} 8.2$

Fig. 4 Growth phenotypes of the insertional mutants M 7, M16, M17 and M19 selected from the phenotypic screen. All strains were grown under three different $\mathrm{CO}_{2}$ conditions. The mutants, cia5, cia3 and pmpl (mutant lacking the $\mathrm{Ci}$ uptake facilitator, LCIB) were used as

for the genes ECAl and RDDP. ECAl codes a Calcium transporting ATPase that is up regulated under low $\mathrm{CO}_{2}$. $R D D P$ codes a RNA dependent DNA polymerase. However, further PCR analysis revealed this gene RDDP is found in multiple copies in $C$. reinhardtii. The CAH8 gene had two independent inserts, one in an intron (the mutant named cah8a, Fig. 3) and the other in the $5^{\prime}$ UTR (named cah $8 \mathrm{~b}$ ). Additional insertions were found in the $5^{\prime} \mathrm{UTR}$ of the genes bestrophin/LCII1 and RHP1. Five other genes had insertions in the $3^{\prime}$ UTRs. Interestingly, we could identify three independent NARI.3 mutants (named narl.3a, $-b$ and $-c$ ). The AphVIII cassette was located in MITCI1 and LCI9 for the other two mutants (Fig. 5; Table 4).

Earlier studies employing insertional mutagenesis showed side effects like deletions of kilobases of DNA (Wang and Spalding 2006). Therefore we also tested the DNA upstream and downstream of the inserted AphVIII cassette. We amplified the junction at both sides of the insertion and found that no major deletions had occurred (Figs. 3, 5). Furthermore, we sequenced the amplified fragments and the $C$. reinhardtii sequence was only altered for 4-20 bases adjacent to the insert in some cases while controls on the plate. All show a growth deficiency under low $\mathrm{CO}_{2}$ conditions. The different $\mathrm{pH}$ levels were $\mathrm{pH} 6.2$ (25 mM MES$\mathrm{KOH})$, pH 7.2 (25 mM MOPS-KOH) and pH 8.2 (25 mM HEPES$\mathrm{KOH})$ to the plates

for other inserts and the genomic DNA sequence near the insert remained unchanged.

Growth on low $\mathrm{CO}_{2}$ and different $\mathrm{pH}$

Several mutants from the PCR based screen had inserts in genes encoding previously known or newly identified potential transporters. A growth study was conducted in order to determine if these insertions in potential transporters like NAR1.3 or MITC11 produced a reduced growth phenotype under low $\mathrm{CO}_{2}$. The mutants were exposed to low ambient and high $\mathrm{CO}_{2}$ at $\mathrm{pH} 6.2,7.2$ and 8.2. The $\mathrm{pH}$ controls the form of inorganic carbon that is predominantly available for use by photosynthesizing $C$. reinhardtii cells. A higher $\mathrm{pH}$ increases the amount of available bicarbonate. From our growth studies no significant differences in growth between the wild-type and the mutants were observed (Supplemental Figure S1). This is not surprising since it has been previously seen that redundancy of $\mathrm{C}_{\mathrm{i}}$ uptake proteins often masks the absence of one protein in the cell and mutants do not show discernible growth deficiencies under low $\mathrm{CO}_{2}$ or high bicarbonate concentrations. Furthermore, most of the 
Table 3 Mutants with low $\mathrm{CO}_{2}$ phenotype

\begin{tabular}{|c|c|c|c|c|c|}
\hline Gene name & $\begin{array}{l}\text { Phytozome } \\
\text { gene ID }\end{array}$ & $\begin{array}{l}\text { Protein } \\
\text { location }\end{array}$ & $\begin{array}{l}\text { Regulated on } \\
\text { low } \mathrm{CO}_{2}\end{array}$ & $\begin{array}{l}\text { Regulated by } \\
\text { CIA5 }\end{array}$ & $\begin{array}{l}\text { Insert } \\
\text { location }\end{array}$ \\
\hline $\begin{array}{l}\text { Glycerol-3-phosphate } \\
\text { dehydrogenase } \\
(M 7)\end{array}$ & Cre01.g053150 & Cytoplasm & Yes- & No & Intron 13 \\
\hline $\begin{array}{l}\text { leucyl-tRNA synthase } \\
\text { (M16) }\end{array}$ & g14211 & Chloroplast & Yes- & No & Intron 13 \\
\hline $\begin{array}{l}F M G 1-B \\
(M 17)\end{array}$ & g9144 & Flagella & Yes- & No & Exon 3 \\
\hline $\begin{array}{l}\text { SRP54-GTPase } \\
\text { (M19) }\end{array}$ & Cre11.g479750 & Mitochondria & No & No & Intron 12 \\
\hline
\end{tabular}

Table 4 Mutants with insertion in genes that were found during the PCR based screen

\begin{tabular}{|c|c|c|c|c|c|}
\hline Gene name & Phytozome gene ID & Protein location & Regulated on low $\mathrm{CO}_{2}$ & Regulated by CIA5 & Insert location \\
\hline $\begin{array}{l}\text { Bestrophin } \\
\text { /LCI11 }\end{array}$ & Cre16.g663450 & Unknown & Yes+ & Yes $^{\mathrm{a}}$ & $5^{\prime}$ UTR \\
\hline CAH8 & Cre09.g405750 & $\begin{array}{l}\text { Plasma membrane/ } \\
\text { Periplasm }\end{array}$ & No & No & $\begin{array}{l}\text { (b) } 1 \times 5^{\prime} \text { UTR } \\
\text { (a) } 1 \times \text { Intron } 1\end{array}$ \\
\hline MITC11 & Cre06.g295400 & Unknown & Yes+ & Yes $^{\mathrm{b}}$ & $3^{\prime}$ UTR \\
\hline NAR1.3 & g4546 & Unknown & No & No & $3 \times 3^{\prime}$ UTR \\
\hline$E C A 1$ & Cre09.g410050 & ER & Yes+ & Yes $^{c}$ & Last exon \\
\hline$L C I 9$ & g9783 & Mitochondrion & Yes+ & Unknown & $3^{\prime} \mathrm{UTR}$ \\
\hline$R H P 1$ & Cre06.g284100 & Unknown & No & $\mathrm{Yes}^{\mathrm{c}}$ & $5^{\prime}$ UTR \\
\hline $\mathrm{RDDP}^{\mathrm{d}}$ & Cre17.g737450 & Unknown & Yes+ & Unknown & Exon 1 \\
\hline
\end{tabular}

a Cluster 14 (Fang et al. 2012)

${ }^{\text {b }}$ Cluster 8 (Fang et al. 2012)

c The transcript levels of these two genes are lower in the CIA5 mutant compared to the wild type according to Fang et al. (2012)

d The RNA directed DNA polymerase (RDDP) is part of a transposon and PCR revealed that only one of the multiple copies of this gene in the Chlamydomonas genome was affected by the insertion

insertions were in non-coding regions of the gene and may not have an effect on the mature protein.

\section{Discussion}

The CCM of $C$. reinhardtii is the best understood CCM from eukaryotic algae (Moroney and Ynalvez 2007). Recently there has been an interest in introducing CCM components into higher plants with the goal of increasing the efficiency of $\mathrm{CO}_{2}$ fixation (Zhu et al. 2010; Price et al. 2011). To maximize the chance of success, a greater understanding of the $C$. reinhardtii CCM is needed. Open questions include the identification of additional inorganic carbon transporters as well as a complete understanding of how these transporters are regulated. Also, while the number and locations of the CAs of $C$. reinhardtii are known, the exact role of each $\mathrm{CA}$ in the $\mathrm{CCM}$ remains to be determined. Finally, we need to determine the components and organization of the pyrenoid. This information will help decide whether the pyrenoid or a structure similar to a pyrenoid is needed before a functional CCM can be realized in a higher plant. With these missing pieces in mind, a screen for additional CCM mutants was initiated. In this screen, cell growth was monitored at high and low $\mathrm{CO}_{2}$ levels with the goal of identifying mutations in new CCM components. While the growth screen was underway, a PCR based screen was also performed. The advantage of this approach was the identification of insertions in target genes of interest, which may or may not have been detected through the phenotypic screen. The combination of the phenotypic and PCR-based screens ensured that insertions in a maximum number of previously identified/unidentified genes involved in the $C$. reinhardtii CCM could be recovered.

The mutants found using these screens

Insertional mutagenesis in $C$. reinhardtii involves the random integration of a foreign piece of DNA into the $C$. 
A

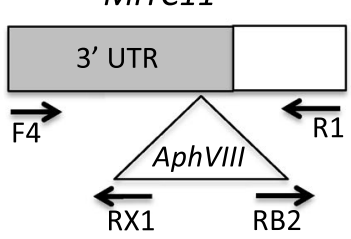

B

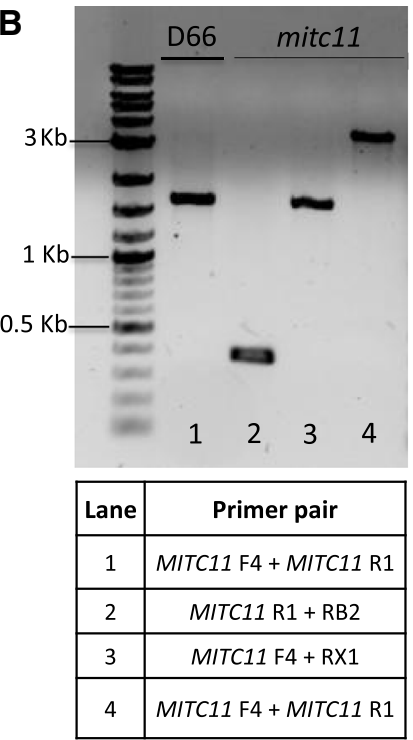

$L C 19$
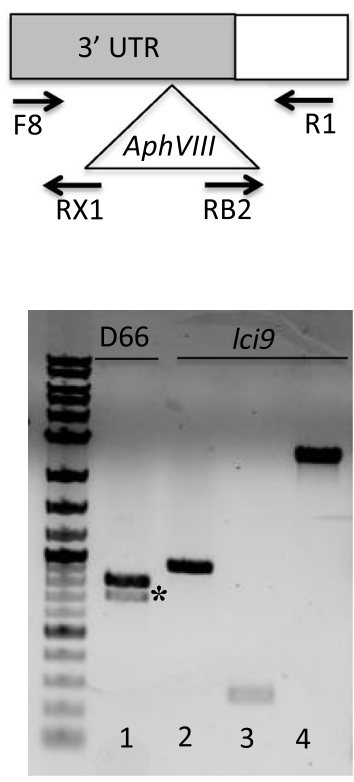

\begin{tabular}{|c|c|}
\hline Lane & Primer pair \\
\hline 1 & $L C I 9 \mathrm{~F} 8+\angle C I 9 \mathrm{R} 1$ \\
\hline 2 & $L C I 9 \mathrm{R} 1+\mathrm{RB} 2$ \\
\hline 3 & $L C I 9 \mathrm{~F} 8+\mathrm{RX} 1$ \\
\hline 4 & $L C I 9 \mathrm{~F} 8+\angle C I 9 \mathrm{R} 1$ \\
\hline
\end{tabular}

LCI11
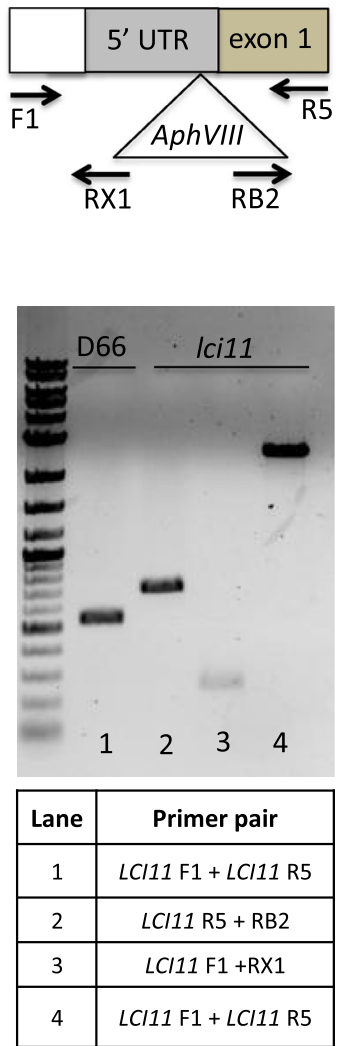

Fig. 5 PCR confirmation of the insertion location for three affected genes of interest. D66 and the mutants with insertions in MITC11, $L C I 9$, and $L C I 11$ were subjected to PCR analysis. a Models of the three genes showing the position of the inserted AphVIII cassette. The insert specific primer RX1 and RB2 were paired with gene specific forward (F) or reverse (R) primers. (B) Amplified fragments from the PCR reactions. DNA from D66 (wild-type without insert) was subjected to PCR with two gene specific primers that span the insert in the mutant (lane 1). RB2 (located near the $3^{\prime}$ end of the insert) was paired with a gene specific primer to analyze the DNA downstream of the insert (lane 2). RX1 (located near the $5^{\prime}$ end of the insert) was used with the appropriate gene specific primer to amplify the DNA upstream of the AphVIII cassette in the mutants (lane 3). The two gene specific primers spanning the insert were used to amply DNA from each mutant (lane 4). In each case the PCR product from the mutants was about $1.8 \mathrm{~kb}$ larger than the wild type PCR product which corresponds to the size of the AphVIII cassette (compare lanes 1 and 4). *Non-specific band. Primer sequences are given in Supplemental Table 2

indicate that the electroporation method results in few large deletions.

Insertions in previously identified and potential CCM genes

One goal of this work was to obtain knockout lines in genes that might play a role in the CCM. Physiological studies on these knockout lines can then be used to determine if a particular gene is required for optimal CCM function. In this study we obtained strains with inserts in three transporter genes bestrophin/LCI11, MITC11 and NAR1.3 and the CA gene CAH8. Thus it is clear that PCR based screening for inserts in genes of interest can help to extend the characterization of the functional roles of many CCM proteins. Combining this with a phenotypic screen based on 
growth defects under low $\mathrm{CO}_{2}$ conditions can lead to the identification of new genes that fill some of the gaps in our understanding of the CCM machinery.

\section{Future perspectives}

The insertional mutagenesis method described here, can be used to identify new components of the $C$. reinhardtii CCM. The advantage of the PCR based screen is that no observable phenotype is needed to identify a mutant with an insert in a specific gene. However, the method is dependent on random insertion events which require a large-scale screen to have a chance of identifying mutants of interest. In addition, the PCR-based screen requires identification of a gene of interest a priori. If the PCR-based screen is coupled with a rigorous screen looking for colonies unable to grow on low $\mathrm{CO}_{2}$, then the odds of finding new components of the CCM increase significantly.

One of the biggest limitations of insertional mutagenesis studies lies in the identification of the gene that is disrupted by the selectable marker. Methods such as iPCR, adapter PCR and map-based cloning have all been used to find the sites of DNA insertion but many interesting mutant colonies have proved intractable to analysis. An adapter-PCR method is currently being tested that should allow for the recovery of flanking DNA sequences in a high percentage of the insertional mutants (Pollock unpublished observations). A highthroughput method of identifying DNA insert locations is also needed. With improved sequencing methods, the development of high-throughput methods to locate DNA insertions appears feasible. Once refined, high-throughput methods have the potential to identify most or all of the inserts in a large population of insertional mutants, allowing the researcher to target genes of interest in a short period of time.

\section{Conclusion}

This report summarizes the progress made in generating C. reinhardtii mutants lacking either previously identified or novel proteins that might play a role in the C. reinhardtii CCM. Using a combination of forward genetics and a PCR based reverse genetics approach; mutants in genes of interest were identified (Figs. 3, 4, 5; Tables 3, 4). This dual-screen strategy provides a powerful tool to find missing links in the CCM of $C$. reinhardtii. It combines the ability to identify newer components of the CCM based on an interesting growth phenotype with the purposeful search of mutations within previously identified genes of interest. These mutants will be needed to judge which CCM components are good candidates for improving photosynthesis in agriculturally important land plants.

\section{References}

Blanco-Rivero A, Shutova T, Roman MJ, Villarejo A, Martinez F (2012) Phosphorylation controls the localization and activation of the lumenal carbonic anhydrase in Chlamydomonas reinhardtii. PLoS ONE 7(11):e49063. doi:10.1371/journal.pone. 0049063

Borkhsenious ON, Mason CB, Moroney JV (1998) The intracellular localization of ribulose-1,5-bisphosphate Carboxylase/Oxygenase in Chlamydomonas reinhardtii. Plant Physiol 116(4):1585-1591

Brueggeman AJ, Gangadharaiah DS, Cserhati MF, Casero D, Weeks DP, Ladunga I (2012) Activation of the carbon concentrating mechanism by $\mathrm{CO}_{2}$ deprivation coincides with massive transcriptional restructuring in Chlamydomonas reinhardtii. Plant Cell 24:1860-1875

Burow MD, Chen ZY, Mouton TM, Moroney JV (1996) Isolation of cDNA clones of genes induced upon transfer of Chlamydomonas reinhardtii cells to low $\mathrm{CO}_{2}$. Plant Mol Biol 31(2):443-448

Colombo SL, Pollock SV, Eger KA, Godfrey AC, Adams JE, Mason CB, Moroney JV (2002) Use of the bleomycin resistance gene to generate tagged insertional mutants of Chlamydomonas reinhardtii that require elevated $\mathrm{CO}_{2}$ for optimal growth. Funct Plant Biol 29(3):231-241

Dent RM, Haglund CM, Chin BL, Kobayashi MC, Niyogi KK (2005) Functional genomics of eukaryotic photosynthesis using insertional mutagenesis of Chlamydomonas reinhardtii. Plant Physiol 137(2):545-556. doi:10.1104/pp.104.055244

Depege N, Bellafiore S, Rochaix JD (2003) Role of chloroplast protein kinase Stt7 in LHCII phosphorylation and state transition in Chlamydomonas. Sci STKE 299(5612):1572

Duanmu D, Miller AR, Horken KM, Weeks DP, Spalding MH (2009) Knockdown of limiting- $\mathrm{CO}_{2}$-induced gene HLA3 decreases $\mathrm{HCO}_{3}{ }^{-}$transport and photosynthetic $\mathrm{C}_{\mathrm{i}}$ affinity in Chlamydomonas reinhardtii. Proc Natl Acad Sci USA 106(14):5990-5995. doi:10.1073/pnas.0812885106

Fang W, Si Y, Douglass S, Casero D, Merchant SS, Pellegrini M, Ladunga I, Liu P, Spalding MH (2012) Transcriptome-wide changes in Chlamydomonas reinhardtii gene expression regulated by carbon dioxide and the $\mathrm{CO}_{2}$-concentrating mechanism regulator CIA5/CCM1. Plant Cell 24(5):1876-1893. doi:10. $1105 /$ tpc. 112.097949

Fukuzawa H, Miura K, Ishizaki K, Kucho KI, Saito T, Kohinata T, Ohyama K (2001) Ccm1, a regulatory gene controlling the induction of a carbon-concentrating mechanism in Chlamydomonas reinhardtii by sensing $\mathrm{CO}_{2}$ availability. Proc Natl Acad Sci USA 98(9):5347-5352. doi:10.1073/pnas.081593498

Genkov T, Meyer M, Griffiths H, Spreitzer RJ (2010) Functional hybrid rubisco enzymes with plant small subunits and algal large subunits: engineered rbcS cDNA for expression in Chlamydomonas. J Biol Chem 285(26):19833-19841. doi:10.1074/jbc. M110.124230

Giordano M, Beardall J, Raven JA (2005) $\mathrm{CO}_{2}$ concentrating mechanisms in algae: mechanisms, environmental modulation, and evolution. Ann Rev Plant Biol 56:99-131. doi:10.1146/ annurev.arplant.56.032604.144052

Gonzalez-Ballester D, Pootakham W, Mus F, Yang W, Catalanotti C, Magneschi L, de Montaigu A, Higuera JJ, Prior M, Galvan A, Fernandez E, Grossman AR (2011) Reverse genetics in Chlamydomonas: a platform for isolating insertional mutants. Plant Methods 7:24. doi:10.1186/1746-4811-7-24 
Gowik U, Westhoff P (2011) The path from C3 to C4 photosynthesis. Plant Physiol 155(1):56-63. doi:10.1104/pp.110.165308

Hanson DT, Franklin LA, Samuelsson G, Badger MR (2003) The Chlamydomonas reinhardtii cia3 mutant lacking a thylakoid lumen-localized carbonic anhydrase is limited by $\mathrm{CO}_{2}$ supply to rubisco and not photosystem II function in vivo. Plant Physiol 132(4):2267-2275

Im CS, Grossman AR (2002) Identification and regulation of high light-induced genes in Chlamydomonas reinhardtii. Plant $\mathrm{J}$ 30(3):301-313

Karlsson J, Clarke AK, Chen ZY, Hugghins SY, Park YI, Husic HD, Moroney JV, Samuelsson G (1998) A novel alpha-type carbonic anhydrase associated with the thylakoid membrane in Chlamydomonas reinhardtii is required for growth at ambient $\mathrm{CO}_{2}$. EMBO J 17(5):1208-1216. doi:10.1093/emboj/17.5.1208

Ma Y, Pollock SV, Xiao Y, Cunnusamy K, Moroney JV (2011) Identification of a novel gene, CIA6, required for normal pyrenoid formation in Chlamydomonas reinhardtii. Plant Physiol 156(2):884-896. doi:10.1104/pp.111.173922

Mariscal V, Moulin P, Orsel M, Miller AJ, Fernandez E, Galvan A (2006) Differential regulation of the Chlamydomonas Nar1 gene family by carbon and nitrogen. Protist 157(4):421-433. doi:10. 1016/j.protis.2006.06.003

Mason CB, Matthews S, Bricker TM, Moroney JV (1991) Simplified procedure for the isolation of intact chloroplasts from Chlamydomonas reinhardtii. Plant Physiol 97(4):1576-1580

McKay R, Gibbs SP, Vaughn K (1991) RuBisCo activase is present in the pyrenoid of green algae. Protoplasma 162(1):38-45

Meyer M, Griffiths $\mathrm{H}$ (2013) Origins and diversity of eukaryotic $\mathrm{CO}_{2}$ concentrating mechanisms: lessons for the future. J Exp Bot 64(3):769-786. doi:10.1093/jxb/ers390

Meyer MT, Genkov T, Skepper JN, Jouhet J, Mitchell MC, Spreitzer RJ, Griffiths H (2012) Rubisco small-subunit alphahelices control pyrenoid formation in Chlamydomonas. Proc Natl Acad Sci USA 109(47):19474-19479. doi:10.1073/pnas. 1210993109

Miura K, Yamano T, Yoshioka S, Kohinata T, Inoue Y, Taniguchi F, Asamizu E, Nakamura Y, Tabata S, Yamato KT, Ohyama K, Fukuzawa H (2004) Expression profiling-based identification of $\mathrm{CO}_{2}$-responsive genes regulated by CCM1 controlling a carbonconcentrating mechanism in Chlamydomonas reinhardtii. Plant Physiol 135(3):1595-1607. doi:10.1104/pp.104.041400

Morita E, Kuroiwa H, Kuroiwa T, Nozaki H (1997) High localization of ribulose-1, 5-bisphosphate carboxylase/oxygenase in the pyrenoids of Chlamydomonas reinhardtii (Chlorophyta), as revealed by cryofixation and immunogold electron microscopy. J Phycol 33(1):68-72

Moroney JV, Ynalvez RA (2007) Proposed carbon dioxide concentrating mechanism in Chlamydomonas reinhardtii. Eukaryot Cell 6(8): 1251-1259

Moroney JV, Husic HD, Tolbert NE (1985) Effect of carbonic anhydrase inhibitors on inorganic carbon accumulation by Chlamydomonas reinhardtii. Plant Physiol 79(1):177-183

Moroney JV, Tolbert NE, Sears BB (1986) Complementation analysis of the inorganic carbon concentrating mechanism of Chlamydomonas reinhardtii. Mol Gen Genet 204:199-203

Moroney JV, Kitayama M, Togasaki RK, Tolbert NE (1987) Evidence for inorganic carbon transport by intact chloroplasts of Chlamydomonas reinhardtii. Plant Physiol 83(3):460-463

Moroney JV, Husic HD, Tolbert NE, Kitayama M, Manuel LJ, Togasaki RK (1989) Isolation and characterization of a mutant of Chlamydomonas reinhardtii deficient in the $\mathrm{CO}_{2}$ concentrating mechanism. Plant Physiol 89(3):897-903

Moroney JV, Ma Y, Frey WD, Fusilier KA, Pham TT, Simms TA, DiMario RJ, Yang J, Mukherjee B (2011) The carbonic anhydrase isoforms of Chlamydomonas reinhardtii: intracellular location, expression, and physiological roles. Photosynth Res 109(1-3):133-149. doi:10.1007/s11120-011-9635-3

Moroney JV, Jungnick N, Dimario RJ, Longstreth DJ (2013) Photorespiration and carbon concentrating mechanisms: two adaptations to high $\mathrm{O}_{2}$, low $\mathrm{CO}_{2}$ conditions. Photosynth Res 117(1-3):121-131. doi:10.1007/s11120-013-9865-7

Mukherjee B (2013) Investigation of the role of putative inorganic carbon transporters in the carbon dioxide concentrating mechanisms of Chlamydomonas reinhardtii. Dissertation

Mukherjee B, Pham TT, Ma Y, Simms TA, Moroney JV (2012) The absence of the periplasmic carbonic anhydrase, CAH1, in the sequenced Chlamydomonas reinhardtii strain CC-503. In: Proceedings of the 15th International Congress on Photosynthesis. Zhejiang University Press, Hangzhou, Beijing, China

Ohnishi N, Mukherjee B, Tsujikawa T, Yanase M, Nakano H, Moroney JV, Fukuzawa $\mathrm{H}$ (2010) Expression of a low $\mathrm{CO}_{2^{-}}$ inducible protein, LCI1, increases inorganic carbon uptake in the green alga Chlamydomonas reinhardtii. Plant Cell 22(9): 3105-3117. doi:10.1105/tpc.109.071811

Pollock SV, Colombo SL, Prout DL Jr, Godfrey AC, Moroney JV (2003) Rubisco activase is required for optimal photosynthesis in the green alga Chlamydomonas reinhardtii in a low- $\mathrm{CO}_{2}$ atmosphere. Plant Physiol 133(4):1854-1861. doi:10.1104/pp.103.032078

Pollock SV, Prout DL, Godfrey AC, Lemaire SD, Moroney JV (2004) The Chlamydomonas reinhardtii proteins $\mathrm{Ccp} 1$ and $\mathrm{Ccp} 2$ are required for long-term growth, but are not necessary for efficient photosynthesis, in a low- $\mathrm{CO}_{2}$ environment. Plant Mol Biol 56(1):125-132. doi:10.1007/s11103-004-2650-4

Price GD (2011) Inorganic carbon transporters of the cyanobacterial $\mathrm{CO}_{2}$ concentrating mechanism. Photosynth Res 109(1-3):47-57. doi:10.1007/s11120-010-9608-y

Price GD, Woodger FJ, Badger MR, Howitt SM, Tucker L (2004) Identification of a SulP-type bicarbonate transporter in marine cyanobacteria. Proc Natl Acad Sci USA 101(52):18228-18233. doi:10.1073/pnas.0405211101

Price GD, Badger MR, von Caemmerer S (2011) The prospect of using cyanobacterial bicarbonate transporters to improve leaf photosynthesis in C3 crop plants. Plant Physiol 155(1):20-26. doi: $10.1104 / p p .110 .164681$

Price GD, Pengelly JJ, Forster B, Du J, Whitney SM, von Caemmerer S, Badger MR, Howitt SM, Evans JR (2013) The cyanobacterial $\mathrm{CCM}$ as a source of genes for improving photosynthetic $\mathrm{CO}_{2}$ fixation in crop species. J Exp Bot 64(3):753-768. doi:10.1093/ jxb/ers 257

Qu Z, Hartzell HC (2008) Bestrophin $\mathrm{Cl}^{-}$channels are highly permeable to $\mathrm{HCO}_{3}{ }^{-}$. Am J Physiol Cell Physiol 294(6):C1371C1377. doi:10.1152/ajpcell.00398.2007

Ramazanov Z, Mason CB, Geraghty AM, Spalding MH, Moroney JV (1993) The low $\mathrm{CO}_{2}$-inducible 36-kilodalton protein is localized to the chloroplast envelope of Chlamydomonas reinhardtii. Plant Physiol 101(4):1195-1199

Raven JA, Giordano M, Beardall J, Maberly SC (2011) Algal and aquatic plant carbon concentrating mechanisms in relation to environmental change. Photosynth Res 109(1-3):281-296. doi:10.1007/s11120-011-9632-6

Raven JA, Giordano M, Beardall J, Maberly SC (2012) Algal evolution in relation to atmospheric $\mathrm{CO}_{2}$ : carboxylases, carbonconcentrating mechanisms and carbon oxidation cycles. Philos Trans R Soc Lond Ser B 367(1588):493-507. doi:10.1098/rstb. 2011.0212

Rawat M, Henk MC, Lavigne LL, Moroney JV (1996) Chlamydomonas reinhardtii mutants without ribulose-1,5-bisphosphate carboxylaseoxygenase lack a detectable pyrenoid. Planta 198(2):263-270

Shimogawara K, Fujiwara S, Grossman A, Usuda H (1998) Highefficiency transformation of Chlamydomonas reinhardtii by electroporation. Genetics 148(4):1821-1828 
Sinetova MA, Kupriyanova EV, Markelova AG, Allakhverdiev SI (2012) Pronina NA (2012) Identification and functional role of the carbonic anhydrase Cah3 in thylakoid membranes of pyrenoid of Chlamydomonas reinhardtii. Biochim BiophysActa 1817(8):1248-1255. doi:10.1016/j.bbabio.2012.02.014

Sizova I, Fuhrmann M, Hegemann P (2001) A Streptomyces rimosus aphVIII gene coding for a new type phosphotransferase provides stable antibiotic resistance to Chlamydomonas reinhardtii. Gene 277(1-2):221-229. doi:10.1016/s0378-1119(01)00616-3

Spalding MH, Spreitzer RJ, Ogren WL (1983a) Carbonic anhydrasedeficient mutant of Chlamydomonas reinhardii requires elevated carbon dioxide concentration for photoautotrophic growth. Plant Physiol 73(2):268-272

Spalding MH, Spreitzer RJ, Ogren WL (1983b) Reduced inorganic carbon transport in a $\mathrm{CO}_{2}$-requiring mutant of Chlamydomonas reinhardii. Plant Physiol 73(2):273-276

Sültemeyer DF, Miller AG, Espie GS, Fock HP, Canvin DT (1989) Active $\mathrm{CO}_{2}$ transport by the green alga Chlamydomonas reinhardtii. Plant Physiol 89(4):1213-1219

Van K, Spalding MH (1999) Periplasmic carbonic anhydrase structural gene (Cahl) mutant in Chlamydomonas reinhardtii. Plant Physiol 120(3):757-764

Villand P, Eriksson M, Samuelsson G (1997) Carbon dioxide and light regulation of promoters controlling the expression of mitochondrial carbonic anhydrase in Chlamydomonas reinhardtii. Biochem J 327(Pt 1):51-57

von Caemmerer S, Quick WP, Furbank RT (2012) The development of $\mathrm{C}_{4}$ rice: current progress and future challenges. Science 336(6089):1671-1672. doi:10.1126/science.1220177

Wang Y, Spalding MH (2006) An inorganic carbon transport system responsible for acclimation specific to air levels of $\mathrm{CO}_{2}$ in Chlamydomonas reinhardtii. Proc Natl Acad Sci USA 103(26):10110-10115. doi:10.1073/pnas.0603402103
Woodger FJ, Badger MR, Price GD (2005) Sensing of inorganic carbon limitation in Synechococcus PCC7942 is correlated with the size of the internal inorganic carbon pool and involves oxygen. Plant Physiol 139(4):1959-1969. doi:10.1104/pp.105.069146

Xiang Y, Zhang J, Weeks DP (2001) The Cia5 gene controls formation of the carbon concentrating mechanism in Chlamydomonas reinhardtii. Proc Natl Acad Sci USA 98(9):5341-5346. doi:10.1073/pnas.101534498

Yamano T, Fukuzawa H (2009) Carbon-concentrating mechanism in a green alga, Chlamydomonas reinhardtii, revealed by transcriptome analyses. J Basic Microbiol 49(1):42-51. doi:10.1002/ jobm. 200800352

Yamano $\mathrm{T}$, Tsujikawa $\mathrm{T}$, Hatano $\mathrm{K}$, Ozawa $\mathrm{S}$, Takahashi $\mathrm{Y}$, Fukuzawa $\mathrm{H}$ (2010) Light and low- $\mathrm{CO}_{2}$-dependent LCIB-LCIC complex localization in the chloroplast supports the carbonconcentrating mechanism in Chlamydomonas reinhardtii. Plant Cell Physiol 51(9):1453-1468. doi:10.1093/pcp/pcq105

Ynalvez RA, Xiao Y, Ward AS, Cunnusamy K, Moroney JV (2008) Identification and characterization of two closely related betacarbonic anhydrases from Chlamydomonas reinhardtii. Physiol Plant 133(1):15-26. doi:10.1111/j.1399-3054.2007.01043.x

Yoshioka S, Taniguchi F, Miura K, Inoue T, Yamano T, Fukuzawa H (2004) The novel Myb transcription factor LCR1 regulates the $\mathrm{CO}_{2}$-responsive gene Cah1, encoding a periplasmic carbonic anhydrase in Chlamydomonas reinhardtii. Plant Cell 16(6):1466-1477. doi:10.1105/tpc.021162

Zhu XG, Long SP, Ort DR (2008) What is the maximum efficiency with which photosynthesis can convert solar energy into biomass? Curr Opin Biotechnol 19(2):153-159. doi:10.1016/j. copbio.2008.02.004

Zhu XG, Long SP, Ort DR (2010) Improving photosynthetic efficiency for greater yield. Ann Rev Plant Biol 61:235-261. doi:10.1146/annurev-arplant-042809-112206 